повышение уровня и качества жизни граждан Российской Федерации, и улучшение имиджа страны как идущей в ногу со временем. Помимо всего вышесказанного, уменьшение потребления природного газа означает снижение выбросов диоксида азота, оксида углерода, бензапирена и иных веществ, выделяющихся при сжигании природного газа. Данный факт окажет положительное влияние на экологию Земли.

Список литературы:

1. Генцлер И.В., Петрова Е.Ф. Сиваев С.Б. Энергосбережение в многоквартирном доме. - Тверь: Научная книга, 2009. - 130 с. - ISBN 978-5-904380-08-9.

2. Свод правил 50.13330.2012 Тепловая защита зданий. - М.: Министерство регионального развития Российской Федерации, 2012.

3. Свод правил 131.13330.2012 Строительная климатология. - М.: Министерство регионального развития Российской Федерации, 2012.

\title{
Емкостной отбор мощности от высоковольтных линий электропередачи
}

\author{
Рожина М.А., аспирант, \\ Северо-Восточный федеральный университет, \\ 2. Якутск \\ E-mail:djmik_90@bk.ru
}

Научный руководитель: о.m.н., профессор Бурянина Н.С.

Проблемы энергетики республики Саха (Якутии) обусловлены ее территорией и не заселенностью. Располагая шестой частью территории России, Республика имеет всего около миллиона населения. Якутия разделяется на 4 энергорайона - это Центральный энергорайона, Западный энергорайон, Южно-Якутский энергорайон и Северный энергорайон. В этих четырех энергорайонах проживает более 900 тысяч человек.

Северный энергорайон, который занимает $2 / 3$ территории всей республики $(2,2$ млн. км²). Общая установленная мощность - 184,9 МВт (электроэнергия) и 92,4 Гкал/ч (теплоэнергия). Основными источниками являются дизельные электростанции, но, кроме этого есть 8 солнечных электростанций и 2 ветроэнергетических установки. Изза большого количества ДЭС остро стоит проблема завоза топлива, и соответственно высока себестоимость электроэнергии.

Bce энергорайоны $\kappa$ настоящему времени не связаны между собой электрическими сетями. Сейчас ведется строительство крупных межсистемных ЛЭП: ВЛ-220 кВ «Чернышевский-Мирный-Ленск-Пеледуй» и ВЛ-220 кВ «Нижний Куранах-Томмот-Майя», которые позволят соединить разрозненные энергорайоны в единую энергосистему.

В перспективе следует учитывать также и связь Якутских электрических сетей с Магаданскими.

В связи с выше изложенным можно сказать, что из-за слабой заселенностью территории Республики. Линии электропередачи 110 - 220 кВ прокладываются вдоль дорог, на которых имеются населенные пункты из нескольких домов, геологические 
партии, сельскохозяйственные угодья и лесопереработывающие станции. Строить подстанции с трансформаторами с учетом их эксплуатации экономически не целесообразно. Поэтому такие населенные пункты снабжаются электроэнергией от малых дизельных генераторов. Квалифицированного обслуживания, как правило, нет. Поэтому часты отключения.

Сложная инфраструктура и транспортная схема завоза топлива; большая протяженность и загруженность линий электропередач, резко-континентальный климат с перепадами температур от $-50^{\circ} \mathrm{C}$ до $+45^{\circ} \mathrm{C}-$ все эти факторы негативно сказываются на качестве электроэнергии. Высока вероятность аварий из-за ненадежности работы электрических сетей.

Альтернативным решением проблемы электроснабжения без строительства мощных трансформаторных подстанций и использования дизельных генераторов является емкостной отбор мощности от линии электропередачи.

Емкостным отборам больших мощностей посвящены работы как в России (СибНИИЭ [1,3,5], Института физико-технических проблем Севера СО РАН [6-10]), $[4,8-10]$, так и за рубежом [12 - 13].

Существует несколько вариантов емкостного отбора мощности. Классическая схема емкостного отбора изображена на рис. 1 [1,14]. Цепь из последовательно включенных емкостей является делителем напряжения. Если к линии 110 кВ включить шесть емкостей, то на последней от линии емкости будет напряжение 10 кВ. Это напряжение является стандартным для трансформаторов 10/0,4 кВ.

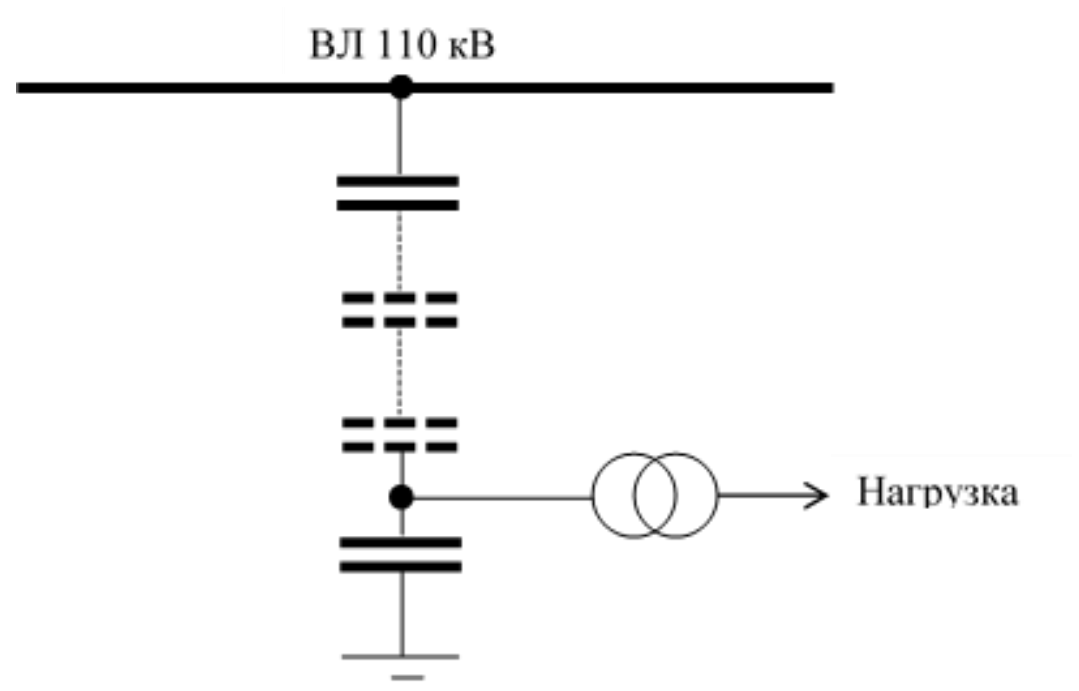

Рис. 1. Классическая схема емкостного отбора мощности

Величина отбираемой мощности от емкостного отбора зависит от мощности конденсаторов. При высоком напряжении первичной обмотки трансформатора отбора, равном 10 кВ, номинальное напряжение конденсаторов тоже должно быть 10 кВ. Минимальная мощность отечественных конденсаторов на такое напряжение составляет 50 кВАр.

Соответственно и мощность отбора должна быть того же порядка. Если же мощность отбора на порядок меньше, использование описанных схем с точки зрения экономики нецелесообразно.

В связи с выше изложенным можно сказать, что в районах Север-Востока РФ целесообразно выполнять отборы малых мощностей от линий электропередачи 110 - 
220 кВ для электроснабжения небольших жилищных объектов, временных горногеологических партий и баз, пунктов питания сотовой связи и др.

Для этой цели рекомендуется выполнять емкостные отборы мощности, причем емкости включать на напряжение 0,4 кВ к обмоткам низкого напряжения однофазных трансформаторов, обмотки высокого напряжения которых включать последовательно в цепь между фазными проводами линии электропередачи и «землей».

Необходимые уровни напряжения обеспечиваются компенсацией реактивной мощности нагрузки.

\section{Список литературы:}

1. Щербаков В.К. Промежуточный отбор мощности в настроенных на полуволну электропередачах последовательно включенными трансформаторами. Известия СО РАН СССР, 11, 1960.

2. Баркан Я.Д. Автоматизация режимов по напряжению и реактивной мощности / Я.Д. Баркан - М.: Энергоатомиздат, 1984. - 160 с.

3. Кобылин А.В. Промежуточный отбор мощности из полуволновой электропередачи / А.В. Кобылин, Г.И. Самородов, С.М. Зильберман, В.П. Кобылин и др. // Электричество. - 2015. - № 6. - С. 4-11

4. .Кобылин В.П. Повышение эксплуатационной надежности электросетевого хозяйства на Севере / В.П. Кобылин - Новосибирск: Наука, 2006. - 223 с.

5. Воропай Н.И. Формирование электрических сетей Республики Саха (Якутия) с учетом развития электроэнергетических центров Востока России / Н.И. Воропай, Г.И. Самородов, В.П. Кобылин, В.А. Седалищев, Р.П. Ли-Фир-Су, А.В. Кобылин // Энергетическая политика. - 2011. - Выпуск 5. - С. 49-59.

6. Samorodov G. Assessment of Impact of Export Transmission System Forced Outages on Power System Reliability / G. Samorodov, T. Krasilnikova, S. Zil-berman, V. Kobylin, A. Drujinin //Asian Energy Cooperation: Mechanisms, Risks, Barries // Proceedins of the International Conference (June 27-29, 2006, Yakutsk, Russia); Edited by N.I. Voropai and D.N. Efimov. Irkutsk: EnergySystemInstitute, 2007. - P. 188-195.

7. Устройство отбора мощности из линии электропередачи [Текст]: пат. 2559024 Рос. Федерации: МПК Н02Ј 3/04 / Кобылин А.В., Кобылин В.П., Королюк Ю.Ф., Лебедев М.П., Бурянина Н.С., Лесных Е.В., Хоютанов А.М., Ли-Фир-Су Р.П., Седалищев В.А.; заявитель и патентообладатель Федеральное государственное бюджетное учреждение науки Институт физико-технических проблем Севера имени В.П. Ларионова СО РАН (RU). - №2014117828/07; заявл. 29.04.2014; опубл. 10.08.2015, Бюл. № 22.

8. Кобылин А.В. Способы отбора мощности от линии электропередачи полуволнового типа и стабилизации напряжения на промежуточной подстанции линии отбора (сценарий на примере связи Усть-Илимской ГЭС - Колымская ГЭС) // Труды VI евразийского симпозиума по проблемам прочности материалов и машин для регионов холодного климата, 24-29 июня 2013 г. г. Якутск. Т. 5. 2013, (№ гос. регистрации 0321304634). - С. 54.

9. Кобылин А.В. Повышение надежности, живучести и эффективности самокомпенсирующейся линии с промежуточным отбором мощности в составе энергообъединения Восточной Сибири, Якутии и Дальнего Востока / А.В. Кобылин, А.М. Хоютанов, В.П. Кобылин и др. // «Наука и образование», научный журнал № 1 (73) 2014. - Якутск: Изд-во Сфера, 2014. - С. 54-58. 
10. Устройство отбора мощности из магистральной линии электропередачи: пат. 2559805 Рос. Федерации: МПК Н 02J 3/06/ Кобылин А.В., Кобылин В.П., Лебедев М.П., Ли-Фир-Су Р.П., Васильев П.Ф., Афанасьев Д.Е., Седалищев В.А., Давыдов Г.И.; заявитель и патентообладатель Федеральное государственное бюджетное учреждение науки Институт физико-технических проблем Севера имени В.П. Ларионова СО РАН (RU). - №2014114749/07; заявл. 14.04.2014; опубл. 10.08.2015, Бюл. № 22.

11. Булашевич Д.Н., Юренков В.Д. Емкостной отбор мощности от линии электропередачи. - М. Госэнергоиздат, 1959, 136 с.

12. Felix, F.Wu, Shuti, Fu. China's Future in Electric Energy / Felix F.Wu, Shuti Fu // IEEE Power and Energy. - 2005. - July/August. - Vol. 3. - № 4.

13. Edris, A. FACTS Technology Development: Au Update / A. Edris // JEEE power engineering review. - 2000. - № 3. - P. 4-15.

14. Устройство емкостного отбора мощности от линии электропередачи [Текст]: пат. 2594890 Рос. Федерации: МПК Н02J 3/04/ Королюк Ю.Ф., Бурянина Н.С., Лесных Е.В., Рожина М.А.; заявители и патентообладатели: Королюк Ю.Ф., Бурянина Н.С., Лесных Е.В. - №2015110388/07; заявл. 23.03.2015; опубл. 20.08.2016, Бюл. № 23.

\section{Критерии системного подхода к энергосбережению в зданиях Республики Саха (Якутия)}

Семенов К.Ю., Слепцов В.В., Сосина С.А., магистранты, Иванова А.В., к.т.н., доцент, Северо-Восточный федеральный университет, 2. Якутск

B cтатье поднимается вопрос системного подхода $\kappa$ энергосбережению $u$ повышению энергоэффективности в зданиях Республики Саха (Якутия). Основное содержание исследования составляет анализ проблем энергосбережения $u$ энергоэффективности в нашем регионе. Рассмотрен и изучен комплекс мероприятий по повышению энергосбережения и энергоэффективности.

This article is about energy saving and increasing of energy efficiency in buildings of the Sakha Republic. The main content of the research is analysis of energy saving problems and energy efficiency in our region. In the article we study different measures of increasing of energy saving and efficiency.

Основная причина высокой энергоемкости отечественных зданий и сооружений кроется в отсутствии системного подхода при проектировании, строительстве и последующей эксплуатации. На первом этапе закладываются все основные параметры здания, в том числе и энергетические. На остальных этапах эти параметры, как правило, только ухудшаются. При этом на стадии эксплуатации проявляются все последствия ошибок в проекте и строительстве.

Нормативно-законодательная база строительства, существующая в России до 1995 г., имела ряд пробелов, к которым можно причислить недостаточные требования к теплозащитным качествам ограждающих конструкций: ориентацию на массовое изготовление энергоемких железобетонных конструкций, недооценку влияния 